\title{
Self-Adjustment of Deaf Students Transfer from Special School to Inclusive School
}

\author{
Nisrina N. Agustin ${ }^{1 *}$ \\ ${ }^{1}$ Universitas Negeri Surabaya \\ ${ }^{*}$ Corresponding author. Email: nisrina.17010664132@mhs.unesa.ac.id
}

\begin{abstract}
This study describes the adjustment process in deaf students who transfer from special schools to inclusive schools. This research uses a qualitative method with case study approaches. The subject for this research is one student in grade 4 elementary school as the main subject. The subject was selected by purposive sampling. Data were collected using semi-structured interviews and analyzed using interpretative phenomenological analysis. The results show that the adjustment of deaf student who transfers from special school to inclusive school include academic adjustment, social adjustment, personal-emotional adjustment, and institutional adjustment. Some adjustments like emotional and social adjustment can be handled because of social support by teachers and peer groups. Because of the difference between the school system and curriculum, the subject shows more problems in academic adjustment.
\end{abstract}

Keywords: Adjustment, Deaf Students, Special Schools, Inclusive Schools.

\section{INTRODUCTION}

Transferring schools is something that can happen to every student-even the transfer of students from special schools to inclusive schools or vice versa. However, in this transfer process, students certainly need to make adjustments to their new school. Selfadjustment can be said as an individual's ability to react effectively and usefully to social realities, situations, and relationships so that the demands or needs in social life are met acceptably and satisfyingly [1]. According to Schneider, success in self-adjustment can be influenced by factors of physical condition, development, and maturity, especially intellectual, social, moral, and emotional, psychological conditions, including experience, learning process, habituation, frustration, and conflict, environmental conditions, especially the home environment, family, school, and community, and the last factor is the cultural factor, including religion[1].

When students can make optimal or appropriate adjustments, they will not experience negative emotions that interfere with their activities at the school, such as low learning achievement and not building safe relationships with teachers at school. This adjustment problem can occur in any student who changes schools, especially if the case is transferring from special schools to inclusive schools or vice versa. This is because there are differences in the school system that will affect student habituation.

Inclusive schools put all students in one class, both those with special needs and regular students [2]. Meanwhile, a special school is a formal educational institution that only serves education for children with special needs [3]. In short, inclusive schools are schools that combine students with special needs with regular students. On the other hand, special schools are designated schools to serve education for children with special needs.

Apart from the type of student, another difference lies in the curriculum aspect. There is a special needs program in the special schools' curriculum, which is a student self-development program according to the type of disability[4]. At the same time, inclusive schools have two types of curriculum, namely, curriculum for regular students and students with special needs. The regular student curriculum focuses on the adaptability of students to the world of work in the future. This is stated in the future competencies of the 2013 curriculum for regular students[5].

This difference in curriculum references can lead to problems in adjusting to the learning system and school goals. In addition, students in special schools are grouped according to the type of disability. Giving material to homogeneous classes can be easier to do. Meanwhile, inclusive schools contain heterogeneous 
students in one class. So, students with special needs are generally accompanied by a special assistant teacher or placed in a separate class from other regular students in inclusive schools.

Another problem also arises from the pattern of communication. Deaf students who have different communication patterns from other hearing friends will certainly experience obstacles in social interaction [6]. Students' success in school, both learning achievement or peer relationships, are strongly influenced by their adjustment.

Self-adjustment is defined as a person's ability to put himself according to the conditions in which he lives, which involves the norms or demands of his environment and self-acceptance to achieve harmony between himself and the environment[7]. The same thing is also conveyed by Schneider, which states that self-adjustment is a process or effort made by a person to resolve various tension conflicts and harmonize demands within himself and the environment in which he lives[2].

Adjustment in a new place is oriented to the development of the individual how the individual can internalize the new habit with himself. This also happens when students change schools. The student also needs to make adjustments in his new school. School adjustment plays an important role in a child's life, and it is like a pillar that underlies the whole life of a child. This is related to children's progress and achievement and their attitudes towards school, anxiety, loneliness, social support, and academic motivation[8]. An adaptation to school can be defined as successful if it meets criteria such as staying in the school, enjoying psychological well-being, and performing well academically[9].

According to Baker and Siryk, there are four dimensions in the adjustment of students to their school[10]. The four dimensions are academic adjustment, social adjustment, personal-emotional adjustment, and institutional adjustment[10].

Academic adjustment is defined as students' success in overcoming various educational demands in school (e.g., motivation to excel academically, academic achievement)[10]. The same thing is also conveyed that academic adjustment involves psychological and behavioral changes when individuals strive to regulate themselves to achieve balance in their new academic environment and meet learning requirements new to the school[11].

Social adjustment relates to students' success in coping with interpersonal-social demands at school—for example, social activities and relationships with other people.
Personal-emotional adjustment relates to how the student's intrapsychic state or matters related to psychology during adjustment at school and the extent to which he experiences psychological distress and somatic problems

Institutional adjustment is the level of student commitment to educational and institutional goals and the level of attachment to the particular institution attended

Very few students with disabilities move from special schools to inclusive schools. In addition, the different types and school systems will certainly affect how is the self-adjustment of the student. Based on the explanation above, the researcher wants to know the problem faced on the self-adjustment process for deaf students who transfers from special schools to inclusive schools.

\section{METHODS}

This study used a qualitative method with a case study approach to describe the adjustment of deaf students who transfer from special schools to inclusive schools. The qualitative case study research was chosen because it can provide an in-depth description of individuals or phenomena [12].

The subject in this study was chosen by purposive sampling technique with the characteristics of deaf students and has been transferred from special schools to inclusive students. Based on these characteristics, it was found that the main subject was a deaf female student, 4th-grade elementary school, and 11 years old who was a transfer student from a mixed special school to a private inclusive school in Gresik, East Java. The significant others in this study were the special assistant teacher, class teacher, and the main subject's mother. Research subject data can be seen in Table 1-research subject data.

Table 1. Research subject data.

\begin{tabular}{|l|l|l|l|}
\hline $\begin{array}{l}\text { Name/ } \\
\text { initial }\end{array}$ & \multicolumn{1}{|c|}{ Position } & Sex & Note \\
\hline ANI & Transfer student & $\mathrm{F}$ & Main subject \\
\hline Bu "A" & $\begin{array}{l}\text { 3rd-grade } \\
\text { homeroom } \\
\text { teacher }\end{array}$ & $\mathrm{F}$ & $\begin{array}{l}\text { Significant } \\
\text { others }\end{array}$ \\
\hline Bu "T" & $\begin{array}{l}\text { 4th-grade } \\
\text { homeroom } \\
\text { teacher }\end{array}$ & $\mathrm{F}$ & $\begin{array}{l}\text { Significant } \\
\text { others }\end{array}$ \\
\hline Bu "F" & $\begin{array}{l}\text { Mother to the } \\
\text { main subject }\end{array}$ & $\mathrm{F}$ & $\begin{array}{l}\text { Significant } \\
\text { others }\end{array}$ \\
\hline Bu "D" & $\begin{array}{l}\text { Special assistant } \\
\text { teacher }\end{array}$ & $\mathrm{F}$ & $\begin{array}{l}\text { Significant } \\
\text { others }\end{array}$ \\
\hline
\end{tabular}


The data collection technique of this research used semi-structured interviews and observation. The interviews were conducted five times with the special assistant teacher, homeroom teacher, and the main subject's mother from September - November 2020. Observations were carried out three times in the main subject's private home.

The data analysis used in this study is interpretative phenomenological analysis (IPA). The IPA analysis technique aims to provide a detailed examination of one's life experience[13]. For this reason, the IPA analysis technique was chosen in this study. Several stages in performing data analysis techniques with IPA. The stages are data collection, processing by looking for research themes, linking research themes, concluding results[13].

The validity of research data is represented by credibility, dependability, confirmability, transferability, and authenticity [14]. This study uses the validity of the credibility perspective obtained through a detailed description of the subject and the confirmability obtained through the congruence of the main subject data results with significant others.

\section{DISCUSSION}

Changing schools is a common thing to do, especially if the new school is considered able to meet the developmental needs of students. However, if the transfer involves two different schools' systems and curriculum, the student will adjust socially and institutionally. It will be challenging if students have some special needs, such as deaf students. They also have to adapt to the school system.

Special schools have curriculum specially designed for students with disabilities. They also provide a teacher who has a special education background. In otherwise, inclusive schools use curriculum designed for regular students and provide some special teachers for students with disabilities. The materials for students with disabilities are usually made from easier versions of regular students' materials. In peer and teacher, special schools usually hold classes with homogeneous students. So, students with disabilities spend more time with their peers who have the same disabilities. In inclusive schools, there are few types of holding the class for students with disabilities. Some schools place the students with disabilities in class with regular students and are accompanied by shadow teachers. Some schools do semi-separative classes for students with disabilities. It means students with disabilities spend some time in class with regular students and some other time in the class designed for them.
Because of these differences, a deaf student who transfers from special schools and inclusive schools faces some difficulties adjusting. To be successful in their new school, deaf students need to do selfadjustment. Based on some research, deaf students in inclusive schools can experience discrimination and lack social belonging. Deaf students who identify themselves with their regular peers tend to have higher PWB[15]. Meanwhile, deaf students who do not identify themselves with their regular peers tend to have lower PWB.

These problems can affect the self-adjustment of deaf students who transfer to inclusive schools. Selfadjustment itself has four components. They are academic adjustment, social adjustment, personalemotional adjustment, institutional adjustment [10]

\subsection{Academic Adjustment}

According to this research, the main subjects showed more problems in academic and institutional adjustment dimensions.

The subject faces some difficulties. As a deaf student, she has difficulty understanding the material in inclusive schools. According to her, the material taught in inclusive schools is different from what she received when she attended special schools. The subject's mother also conveyed a similar message. According to the mother's observations when accompanying her children to study, the material taught in inclusive schools has a heavier weight. Even though, according to the class teacher, the material for the subject has been lowered in difficulty. However, the subject's learning scores mostly did not reach the minimum criteria target.

This problem may occur because of the lack of understanding of inclusive school teachers on deaf students' needs and the differential curriculum, a designated curriculum for students with disabilities. The teachers at inclusive schools tend to assume that teaching students with disabilities is an extra workload instead of their whole responsibility[16]. The teachers' inability to understand the curriculum and the needs of students with disabilities can affect the learning process.

Another factor affecting the subject's academic adjustment in inclusive school is the attachment that exists in the relationship between the subject and her teachers. The quality of instructional support and positive teacher-student relationships affected student engagement and, directly, school grades and student attitudes towards school and learning[17]. With the subject of class 7 th grade students, the quality of the teacher's instructional support affects mathematics scores, while the positive emotional relationship between teachers and students affects students' attachment and mathematics scores. The subject's attachment to her relationship with teachers can be said 
to have not been well-formed. Face-to-face meetings for two months before conducting distance learning due to the covid-19 pandemic made it difficult for the subject to interact directly with her teachers. In addition, the subject's tendency to shyness also makes it difficult to build relationships with new people.

Another factor that can affect the subject's academic adjustment is her special condition. Deaf children have obstacles in verbal communication, both expressively (speaking) and receptively (understanding other people's speech). So they are more functional and prioritize the sense of sight to receive stimuli and process stimuli from outside than their sense of hearing [18]. This can be seen from how it is easier for the subject to understand commands when accompanied by a visual presentation. Like when the subject can understand the process of baby formation from video learning and understand patterns more quickly with colors than numbers.

\subsection{Social Adjustment}

Social adjustment is related to student success in overcoming interpersonal-social problems at school, for example, social activities and relationships with others. In this dimension, the subject does not seem to face many problems. One factor is that many of his friends at his new school were friends in kindergarten. In addition, in the same class, she attends there are two deaf students. The support from fellow deaf students makes her socially more adaptable, especially in the class. Social support is a factor that influences the individual's self-adjustment.

The research shows a correlation of 0.5 between social support and self-adjustment in deaf students at vocational schools in Surabaya[2]. Social support is also one of the predictors of the success of student adjustment. School adjustment is not only happening on success in the academic field, but also the desire to stay at the school, enjoy psychological well-being, and perform well academically[9]. Social support itself is one dimension of psychological well-being[19]. Because of supportive peers in her new school, the subject can engage in social activities better.

However, in adult social groups such as teachers, she still does not show good attachment, which many things can cause. Even so, several factors can be a source of problems, namely the fear of negative evaluations [7]. This is also illustrated by the subject's attitude when in learning, which often feels doubtful when answering questions from her teacher. In addition, she always asks the teacher about the correctness of her answers if she wants to answer questions. This attitude can be an indication of low self-esteem, but it needs further explanation. Teachers also find it difficult to give instruction or communicate with the subject. The teachers usually delegate the instruction to the subject's friends, who are deaf students too. The difference in the way of communication used by the subject as a deaf student and the teachers may cause misunderstanding. The subject who has come from a special school is accustomed to using sign language. On the other side, teachers in inclusive schools do not understand sign language. That factor can be an obstacle to the communication between the subject and her teachers

\subsection{Personal-Emotional Adjustment}

Personal-emotional adjustment relates to how the student's intrapsychic state or matters related to psychology during adjustment at school and the extent to which he experiences psychological distress and somatic problems [10].

In this dimension, the subject does not show any significant problem related to her personal-emotional adjustment. The process of her personal-emotional adjustment can be seen from how much distress she has experienced when transferring to an inclusive school.

Discrimination is one of the factors that can influence the psychological well-being of someone [20]. Based on the interview with the subject's 3rd-grade homeroom teacher, she does not experience any bullying related to her special condition as a deaf student. Other than that, most of her classmates were her friend when she was in kindergarten. In terms of building relationships with her classmates, she has no significant problems. Furthermore, the subject spends more time during lunch break with her classmates. So, she also does not receive discrimination from her junior or senior in school. These findings are also similar to a previous study that states if students with hearing impairment at inclusive schools will be more adaptable to interact with other regular studentsa[3].

\subsection{Institutional Adjustment}

Institutional adjustment is the student's commitment to educational and institutional goals and the level of attachment to the particular institution they attend. There are difficulties in identifying the self-adjustment of the subject in this dimension. Due to pandemic covid19 and the rise of online learning, researchers can not find any indication of self-adjustment to the new or inclusive school she attends. The important point is that the subject does not show any sign of school refusing.

\section{CONCLUSION}

From the explanation above, it is found that the selfadjustment process of a deaf student who transfers from special schools to inclusive schools consists of academic adjustment, social adjustment, institutional adjustment, and personal-emotional adjustment. Among the four 
dimensions of self-adjustment, academic adjustment is a dimension that has more problems than other dimensions. It can happen because of differences in the school's system and curriculum. The readiness of the teacher in the inclusive school can be a factor that influences the self-adjustment of deaf students who transfer from special school to inclusive school.

\section{REFERENCES}

[1] S. Maslihah, "Studi tentang hubungan dukungan sosial, penyesuaian sosial di lingkungan sekolah dan prestasi akademik siswa SMP IT As-syfa boarding school Subang Jawa Barat.," J. Psychol. Undip, vol. 10, no. 2, pp. 103-115, 2011, DOI: https://doi.org/10.14710/jpu.10.2.103-114.

[2] S. A. Hasan and M. M. Handayani, "Hubungan antara Dukungan Sosial Teman Sebaya dengan Penyesuaian Diri Siswa Tunarungu di Sekolah Inklusi," J. Psikol. Pendidik. dan Perkembangan, vol. 3, no. 2, pp. 128-135, 2014.

[3] N. Adwiasa, "Perbedaan Penyesuaian Diri Antara Siswa Tunarungu Di Sekolah Inklusi Dan Di Sekolah Luar Biasa," J. Psikol. Pendidik. dan Perkemb., vol. 2, no. 1, pp. 1-6, 2013.

[4] SLB A Pembina Tingkat Nasional, "Kurikulum 2013." http://slbapembinajakarta.sch.id/kurikulum2013/ (accessed Nov. 24, 2020).

[5] Ministry of education and culture, "Concept and Implementation of Curriculum," 2013.

[6] D.Wasito, D. Sarwindah, and W. Sulistiani, "Penyesuaian Sosial Remaja Tunarungu yang Bersekolah di Sekolah Umum," INSAN, vol. 12, no. 3, pp. 138-152, 2010.

[7] D. V. Fakhriyani, Kesehatan Mental. Pamekasan: Duta Media Publishing, 2019.

[8] P. K. Lakhani, J. Kusum, and C. P. Kanwar, "School Adjustment, Motivation, and Academic Achievement among Students," Int. J. Res. Soc. Sci., vol. 7, no. 10, pp. 333-348, 2017.

[9] R. Arjanggi and L. P. S. Kusumaningsih, "College Adjustment of First Year Students: The Role of Social Anxiety," J. Educ. Heal. Community Psychol., vol. 5, no. 1, pp. 30-39, 2016.

[10] M. A. Taylor and D. A. Pastor, "A Confirmatory Factor Analysis of the Student Adaptation to College Questionnaire," Educ. Psychol. Meas., vol. 67, no. 2, pp. 1002-1018, 2007, DOI: doi:10.1177/0013164406299125.

[11] J. R. Anderson, Y. Guan, and Y. Koc, "The academic adjustment scale: Measuring the adjustment of a permanent resident or sojourner students," Int. J. Intercult. Relations, vol. 54, pp. $68-76$ 2018,

DOI: https://doi.org/10.1016/j.ijintrel.2016.07.006.

[12] Y. Rashid, A. Rashid, M. A. Warraich, S. S. Sabir, and A. Waseem, "Case Study Method: A Step-byStep Guide for Business Researchers," Int. J. Qual. Methods, 2019, DOI: https://doi.org/10.1177/1609406919862424.

[13] J. A. Smith and P. Shinebourne, Interpretative phenomenological analysis: theory, method, and research. London: SAGE Publications, 2009.

[14] S. Elo, M. Kääriäinen, O. Kanste, T. Pölkki, K. Utriainen, and H. Kyngäs, "Qualitative Content Analysis: A Focus on Trustworthiness," SAGE Open, vol. 4, no. 1, 2014, doi: https://doi.org/10.1177/2158244014522633.

[15] J. Dammeyer, M. Chapman, and M. Marschark, "Experience of Hearing Loss, Communication, Social Participation, and Psychological Well-Being Among Adolescents With Cochlear Implants," Am. Ann. Deaf, vol. 163, no. 4, pp. 424-439, 2018, [Online]. Available: https://www.jstor.org/stable/26529752.

[16] P. Kantavong, Sujarwanto, S. Rerkjaree, and Budiyanto, “A comparative study of teacher's opinions relating to inclusive classrooms in Indonesia and Thailand," Kasetsart J. Soc. Sci., vol. 38, no. 3, pp. 291-296, 2017, DOI: doi:10.1016/j.kjss.2016.05.005.

[17] K. Ksenija, "Attachment in the student-teacher relationship as a factor of school achievement," Teach. Innov., vol. 28, no. 3, pp. 167-188, 2015, doi: doi:10.5937/inovacije1503167K.

[18] A. Saputri, “Analisis Pola Komunikasi Pada Siswa Tunarungu Di SMALB Dharma Asih Kota Pontianak," J. Pendidik. Dan Pembelajaran Khatulistiwa, vol. 6, no. 6, pp. 1-11, 2017.

[19] C.D. Ryff, "Psychological Well-Being Revisited: Advances in the Science and Practice of Eudaimonia," Psychother. Psychosom., vol. 83, pp. 10-28, 2014, DOI: doi:10.1159/000353263.

[20] N. Nader-Grosbois, "Self-perception, selfregulation, and metacognition in adolescents with intellectual disability," Res. Dev. Disabil., vol. 35, no. 6, pp. 1334-1348, 2014, DOI: doi:10.1016/j. ridd.2014.03.033. 